\title{
Proterozoic Ocean Chemistry and Evolution: A Bioinorganic Bridge?
}

\author{
A. D. Anbar ${ }^{1 *}$ and A. H. Knoll ${ }^{2}$
}

Recent data imply that for much of the Proterozoic Eon (2500 to 543 million years ago), Earth's oceans were moderately oxic at the surface and sulfidic at depth. Under these conditions, biologically important trace metals would have been scarce in most marine environments, potentially restricting the nitrogen cycle, affecting primary productivity, and limiting the ecological distribution of eukaryotic algae. Oceanic redox conditions and their bioinorganic consequences may thus help to explain observed patterns of Proterozoic evolution.

O $\mathrm{n}$ the present-day Earth, $\mathrm{O}_{2}$ is abundant from the upper atmosphere to the bottoms of ocean basins. When life began, however, $\mathrm{O}_{2}$ was at best a trace constituent of the surface environment. The intervening history of ocean redox has been interpreted in terms of two long-lasting steady states: anoxic oceans (or nearly so) that persisted for some 2000 million years, followed by essentially modern oceans of comparable duration. Here, we review recent evidence pointing to the presence of "intermediate" oceans-oxic at the surface but anoxic and sulfidic at depth - that may have persisted for more than 1000 million years, originating some time after $\sim 1800$ million years ago (Ma). Aspects of the evolutionary pattern recorded by fossils of Proterozoic eukaryotes may be explained by the scarcity of biologically essential trace metals in such sulfidic seas, suggesting a bioinorganic bridge between environmental and biological evolution.

\section{Sulfidic Deep Oceans}

The classical argument that the deep oceans became oxidized at $\sim 1800 \mathrm{Ma}$ is based principally on the disappearance of banded iron formations (BIFs; Fig. 1A). BIFs are massive, laterally extensive and globally distributed chemical sediment deposits that consist primarily of Fe-bearing minerals and silica. Their formation seems to require anoxic deep waters to deliver hydrothermally derived $\mathrm{Fe}^{2+}$ to locations where deposition took place [e.g., (1-3)]. Oxygenation of the oceans would produce $\mathrm{Fe}^{3+}$, which readily hydrolyz-

${ }^{1}$ Department of Earth and Environmental Sciences and Department of Chemistry, University of Rochester, Rochester, NY 14627, USA. 'Department of Organismic and Evolutionary Biology, Harvard University, Cambridge, MA 02138, USA.

*To whom correspondence should be addressed. Email: anbar@earth.rochester.edu es and forms insoluble Fe-oxyhydroxides, thus removing $\mathrm{Fe}$ and precluding BIF formation. This reading of the stratigraphic record made sense because independent geochemical evidence indicates that the partial pressure of atmospheric oxygen $\left(\mathrm{PO}_{2}\right)$ rose substantially about 2400 to $2000 \mathrm{Ma}(4-7)$.

Because the solubility of Fe-sulfides is also low, however, the disappearance of BIF can alternatively be taken to indicate that the deep oceans became sulfidic, rather than oxic, after $1800 \mathrm{Ma}$. According to this scenario, recently advanced by Canfield (8), deep sea water became more reducing rather than more oxidizing at this time despite the rise in atmospheric oxygen. Ocean anoxia might have persisted into the Neoproterozoic (9), when $\mathrm{C}$ and $\mathrm{S}$ isotopic data indicate another increase in the oxidation state of Earth surface environments (10-13).

At first blush, sulfidic oceans appear counterintuitive in the face of contemporaneous atmospheric oxygenation. However, simple modeling of ocean redox suggests that deep waters would have remained anoxic if $\mathrm{PO}_{2}$ had been $<0.07 \mathrm{~atm}$ and if biological productivity, which delivers reduced $\mathrm{C}$ to the deep sea, was at all comparable to that of modern oceans (8). It is likely that $\mathrm{PO}_{2}$ did not approach modern values until the Neoproterozoic $(14,15)$. Sulfidization follows from the fact that the concentration of hydrogen sulfide $\left(\mathrm{H}_{2} \mathrm{~S}\right)$ in seawater is affected by the supply of both organic $\mathrm{C}$ and sulfate $\left(\mathrm{SO}_{4}{ }^{2-}\right)$-which constitute a source of $\mathrm{H}_{2} \mathrm{~S}$ when their reaction is catalyzed by dissimilatory bacterial sulfate reduction (BSR) - and by the availability of $\mathrm{O}_{2}$, which acts as a reactive sink for $\mathrm{H}_{2} \mathrm{~S}$ and inhibits BSR. Today, pervasive $\mathrm{O}_{2}$ limits $\mathrm{H}_{2} \mathrm{~S}$ concentrations, as has generally been the case for the Phanerozoic Eon. In the Archean and early Paleoproterozoic, the low solubility of reduced $\mathrm{S}$ minerals in igneous and sedimentary rocks during weathering under a nearly anoxic atmosphere limited the $\mathrm{SO}_{4}{ }^{2-}$ supply, keeping $\mathrm{H}_{2} \mathrm{~S}$ concentrations low. In contrast, weathering under a moderately oxidizing mid-Proterozoic atmosphere would have enhanced the delivery of $\mathrm{SO}_{4}{ }^{2-}$ to the anoxic depths. Assuming biologically productive oceans, the result would have been higher $\mathrm{H}_{2} \mathrm{~S}$ concentrations during this period than either before or since (8).

Is there any evidence for such a world? Canfield and his colleagues have developed an argument based on the $\mathrm{S}$ isotopic composition of biogenic sedimentary sulfides, which reflect $\mathrm{SO}_{4}{ }^{2-}$ availability and redox conditions at their time of formation $(16-18)$. When the availability of $\mathrm{SO}_{4}{ }^{2-}$ is strongly limited $\left(\mathrm{SO}_{4}{ }^{2-}\right.$ concentration $<\sim 1 \mathrm{mM}$, $\sim 4 \%$ of that in present-day seawater), $\mathrm{H}_{2} \mathrm{~S}$ produced by BSR is depleted in ${ }^{34} \mathrm{~S}$ by $\sim<5$ per mil (\%o) relative to dissolved $\mathrm{SO}_{4}{ }^{2-}$. Fractionation increases to as much as $\sim 45 \%$ o when $\mathrm{SO}_{4}{ }^{2-}$ is more freely available. Larger fractionations (45 to 70\%) appear to require a cyclical process in which ${ }^{34} \mathrm{~S}$-depleted sulfides are reoxidized to elemental sulfur $\left(\mathrm{S}^{0}\right)$, followed by bacterial disproportionation of $\mathrm{S}^{0}$ to produce extremely ${ }^{34} \mathrm{~S}$-depleted $\mathrm{H}_{2} \mathrm{~S}$ $(19,20)$. Hence, $\mathrm{S}$ isotope fractionation $>\sim 45 \%$ between sedimentary sulfides and sulfates may indicate increased oxygenation of the environment (21).

Several changes in $\mathrm{S}$ isotope systematics are seen in the Precambrian geological record (Fig. 1B) (22). BSR appears to have been in place by at least $\sim 3470 \mathrm{Ma}$, as suggested by a fractionation of up to $21 \%$ o (mean $\sim 11 \%$ ) between $\mathrm{S}$ in evaporitic barite deposits and sulfide inclusions found within these sediments (23). However, in rocks older than $2400 \mathrm{Ma}, \Delta^{34} \mathrm{~S}$ (the difference in $\delta^{34} \mathrm{~S}$ between marine sulfate minerals - which record $\delta^{34} \mathrm{~S}$ of seawater $\mathrm{SO}_{4}{ }^{2-}$ - and co-occurring sulfides) is typically $\ll 20 \%$. From this time until 800 to $600 \mathrm{Ma}, \Delta^{34} \mathrm{~S}$ reaches $\sim 40 \%$, near the maximum associated with BSR, but rarely exceeds this value. Only in later Neoproterozoic and Phanerozoic rocks does $\Delta^{34} \mathrm{~S}$ approach the modern maximum of $\sim 65 \%$.

The biogeochemical record of $\mathrm{S}$ is thus consistent with $\mathrm{SO}_{4}{ }^{2-}$-poor Archean oceans giving way to modest $\mathrm{SO}_{4}{ }^{2-}$ concentrations, and consequent global enhancement of BSR, in the Paleoproterozoic. Presumably, the rise of a moderately oxidizing atmosphere facilitated, for the first time, the delivery of large quantities of $\mathrm{SO}_{4}^{2-}$ to the oceans $(8,24)$. The observation that $\Delta^{34} \mathrm{~S}<45 \%$ during the mid-Proterozoic 


\section{SCIENCE'S COMPASS}

suggests that the oceans were oxygenated only to shallow depths during this time, and that more extensive oxygenation did not occur until late in the eon (12).

If sulfidic conditions were common through much of the Proterozoic Eon, independent geochemical redox indicators should provide evidence of anoxia. In addition, seawater $\mathrm{SO}_{4}{ }^{2-}$ concentrations in the Proterozoic, although greatly elevated over Archean values, should have been lower than at present; this prediction can be tested by looking for "reservoir" effects in pyrite $\delta^{34} \mathrm{~S}$ within individual sedimentary basins (25).

Both predictions are met in superbly preserved black shales deposited $\sim 1730$ and $1640 \mathrm{Ma}$ during maximum flooding of the Tawallah and McArthur basins, respectively, in northern Australia. Two geochemical indicators reliably differentiate sediments formed beneath oxic and sulfidic waters in the Black Sea $(26-28)$ and in Mesozoic marine basins (29). The ratio of "highly reactive" Fe (Fe present in pyrite or oxides/hydroxides) to total $\mathrm{Fe}$ tends to be higher in sediments deposited beneath sulfidic waters than in sediments deposited beneath an oxic water column. Similarly, the "degree of pyritization" (the proportion of reactive Fe incorporated into pyrite) tends to be substantially higher beneath sulfidic bottom waters. Both indicators show that Tawallah and McArthur shales accumulated beneath sulfidic waters (30). Moreover, relative to the Black Sea, Cariaco Basin, and other modern sulfidic settings $(27,31)$, sedimentary pyrites in Tawallah and McArthur shales are markedly ${ }^{34}$ S-enriched, suggesting that BSR strongly depleted the $\mathrm{SO}_{4}{ }^{2-}$ reservoir in deep waters of these basins. Given reasonable estimates of primary production in surface waters, this indicates a seawater $\mathrm{SO}_{4}{ }^{2-}$ reservoir as much as $90 \%$ lower than today's (30).

Elsewhere, large and systematic stratigraphic variation in $\delta^{34} \mathrm{~S}$ of sedimentary pyrites $(>20 \%$ o over tens to hundreds of meters of section) is seen in 1470- to 1440 Ma rocks from the Belt Supergroup, Montana, suggestive of reservoir effects. This finding provides evidence of episodic $\mathrm{SO}_{4}{ }^{2-}$ limitation in another mid-
Proterozoic basin, as might be expected in a low- $\mathrm{SO}_{4}{ }^{2-}$ ocean $(32,33)$.

Gypsum and anhydrite $\left(\mathrm{CaSO}_{4}\right.$ minerals) are common in rocks that formed along the margins of $\sim 1200$-Ma carbonate platforms in the Bylot Supergroup, North America, but are scarce in older rocks. $\delta^{34} \mathrm{~S}$ in these minerals varies by up to $10 \%$ over $300 \mathrm{~m}$ of section (34). The appearance of extensive $\mathrm{CaSO}_{4}$ deposits indicates that $\mathrm{SO}_{4}{ }^{2-}$ inventories be-

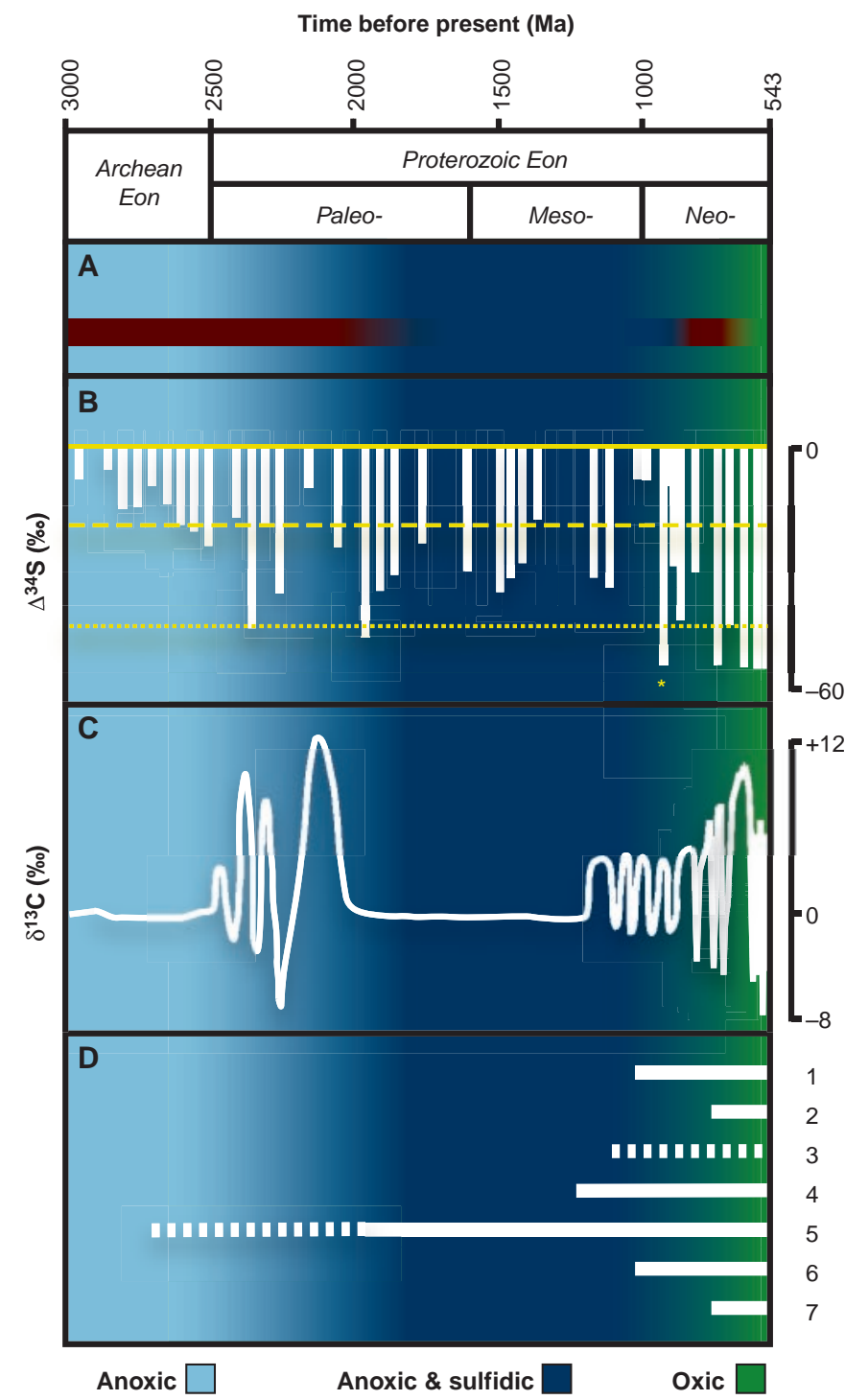

Fig. 1. Biological and geochemical changes during the Proterozoic Eon. Color gradations denote postulated changes in deep sea redox. (A) Periods of deposition of banded iron formations. (B) Range of values of $\Delta^{34} \mathrm{~S}$, the difference in $\delta^{34} \mathrm{~S}$ between coeval marine sulfides and sulfates. Dashed line: $\Delta^{34} \mathrm{~S}=20 \%$, the maximum Archean value. Dotted line: $\Delta^{34} S=45 \%$, the maximum fractionation associated with single-step BSR. Asterisk: $\Delta^{34}$ S determined from a single sample, and thus not well constrained. (C) Range of values of $\delta^{13} C_{\text {carb }}$ (after a compilation by A. J. Kaufman). The frequency and magnitude of variations in the Paleoproterozoic are somewhat uncertain. (D) Eukaryotic evolution, as indicated by the first appearances of body fossils (solid lines) and molecular biomarkers (dotted lines), including chlorophytes (1), ciliates (2), dinoflagellates (3), rhodophytes (4), eukaryotes of unknown affinities, possibly stem groups (5), stramenopiles (6), and testate amoebae (7). See text for geochemical references. Fossil distributions from (147). gan to rise at this time, but the observed ell below present-day levels until the end Proterozoic Eon (36).

As yet, detailed stratigraphic analyses are oo few to demonstrate unequivocally the global nature of sulfidic deep waters in midProterozoic oceans. However, available data point to globally extensive $\mathrm{BSR}$ in low- $\mathrm{SO}_{4}{ }^{2-}$ oceans, ocean oxygenation insufficient to support $\mathrm{S}^{0}$ disproportionation, and sulfidic bottom waters in at least some marine basins during this time. We must therefore take seriously the proposition that the deep oceans were persistently sulfidic for much of our planet's middle age.

\section{Biology of Mid-Proterozoic Oceans}

What was biology like in mid-Proterozoic oceans? Hints come from $\mathrm{C}$ isotopes and fossils, which show distinctive stratigraphic trends that correlate broadly with the inferred redox history.

Secular variation of $\mathrm{C}$ isotopes in marine carbonates $\left(\delta^{13} \mathrm{C}_{\text {carb }}\right)$ reflects changes in the ratio of organic to inorganic $\mathrm{C}$ removed from the oceans during burial in sediments (37). This ratio (and hence $\left.\delta^{13} \mathrm{C}_{\text {carb }}\right)$ may increase when enhanced tectonic activity increases the opportunities for organic C burial (38). Enhanced tectonic activity may also affect this ratio by increasing the supply of $\mathrm{P}$ to the oceans (39), stimulating primary production where $\mathrm{N}$ is not limiting.

Unusually large variations in $\delta^{13} \mathrm{C}_{\text {carb }}$ characterize rocks that formed at the beginning and the end of the Proterozoic Eon (Fig. 1C), both times of widespread glaciation and increasing oxidation of the biosphere $(5,10,40-42)$. The intervening interval is equally striking for its lack of variation; $\delta^{13} \mathrm{C}_{\text {carb }}$ varies only within the limits of $0 \pm 2 \%$ between $\sim 1850$ and $1250 \mathrm{Ma}$ (Fig. 1C), documenting unique long-term stability of the $\mathrm{C}$ cycle (43-45). This stasis gave way to moderate variation (similar to that seen in Phanerozoic carbonates) after $\sim 1250 \mathrm{Ma}(45-47)$, before the onset of large-amplitude $\delta^{13} \mathrm{C}_{\text {carb }}$ variations at $\sim 800 \mathrm{Ma}$. 


\section{SCIENCE'S COMPASS}

It has been hypothesized that mid-Proterozoic $\delta^{13} \mathrm{C}_{\text {carb }}$ stasis reflects tectonic quiescence during this time, in contrast to major continental rifting and orogenesis at the beginning and end of the eon (44). However, Phanerozoic-scale $\delta^{13} \mathrm{C}_{\text {carb }}$ variations might still be expected before $1250 \mathrm{Ma}$, as the mid-Proterozoic was not a period without variations in tectonic activity (48). Hence, $\delta^{13} C_{\text {carb }}$ stasis appears to call for attenuation of the link between tectonism and primary production. Such attenuation might follow naturally if $\mathrm{P}$ were not the limiting nutrient during this time. Increased availability of $\mathrm{P}$ in the mid-Proterozoic oceans compared to the Archean and Paleoproterozoic goes hand-inhand with the end of BIF deposition and the advent of sulfidic oceans at $\sim 1800$ Ma because $\mathrm{Fe}$ oxides are a sink for dissolved P (49), and because $\mathrm{P}$ is released from organic-rich sediments under sulfidic conditions $(50,51)$.

A changed nutrient regime in mid-Proterozoic oceans is consistent with suggestions of lower overall productivity at this time as compared to the Paleoproterozoic, Neoproterozoic, and Phanerozoic. The evidence again comes from $\mathrm{C}$ isotopes. First, the average value of $\delta^{13} \mathrm{C}_{\text {carb }}$ in mid-Proterozoic carbonates appears to be $\sim 1.5 \%$ lower than in Paleoproterozoic, Neoproterozoic, and Phanerozoic carbonates $(38,43-45,52,53)$, as would be expected from a decrease in the proportion of carbon buried as organic $\mathrm{C}$ due to depressed mid-Proterozoic primary productivity. Second, the export of ${ }^{13} \mathrm{C}$-depleted organic $\mathrm{C}$ from surface waters reflects rates of primary production (54). In consequence, one would expect low productivity to be accompanied by a relatively small depth gradient in the isotopic composition of dissolved inorganic C. Data from several Mesoproterozoic basins are consistent with this notion $(43,44)$. In contrast, gradients for both earlier Paleoproterozoic and later Neoproterozoic oceans are larger $(55,56)$. The apparent absence of extensive continental ice sheets during the long interval between the large ice ages of the early Paleoproterozoic (42) and later Neoproterozoic (57) is also consistent with nutrient limitation of the biological $\mathrm{C}$ pump, although other factors undoubtedly contributed to the long-term maintenance of a mid-Proterozoic greenhouse.

Like $\mathrm{C}$ isotopes, fossils of presumed eukaryotes show distinct mid- and late Proterozoic distributions (Fig. 1D). Eukaryotic fossils appear in the geologic record as early as 1800 to $2100 \mathrm{Ma}(58,59)$, and recent organic geochemical studies indicate that at least stem eukaryotes diverged as early as 2700 Ma (60). Despite this early differentiation, photosynthetic protists appear to have played a limited role in mid-Proterozoic ecosystems. Fossil diversity is low (59), and eukaryotic biomarker molecules are limited in both abundance and diversity (61). Moreover, photosynthetic eukaryotes appear to have been most abundant and diverse in shoreline environments, despite the stresses that fluctuating salinity and temperature impose on such habitats (62).

Bangiophyte red algae occur in silicified tidal flat carbonates deposited around 1200 $\mathrm{Ma}$ (63), and conspicuously ornamented acritarchs also occur in rocks this age or older (64-66). Only in the latest Proterozoic, however, did morphologically complex, larger eukaryotic phytoplankton and branching macroalgal benthos diversify markedly in open shelf settings (67-71). Thus, the fossil record of algal diversification parallels, at least broadly, the history of ocean oxidation inferred from $\mathrm{S}$ isotopes (Fig. 1).

\section{Trace Metals and the Nitrogen Cycle}

If widespread sulfidic conditions were a unique feature of the mid-Proterozoic oceans, as suggested by $\mathrm{S}$ isotopes and other indicators, it is perhaps not surprising that $\mathrm{C}$ isotopes and fossils also mark this period as unique with respect to $\mathrm{C}$ cycling and evolution. But what might relate these seemingly unrelated phenomena?

The connection may lie in the effect of sulfidic conditions on the availability of redoxsensitive bioessential metals in the oceans (72, 73). In particular, $\mathrm{Fe}$ and $\mathrm{Mo}$, important for biological $\mathrm{N}_{2}$ fixation (the reduction of $\mathrm{N}_{2}$ to biologically useful ammonia) and nitrate $\left(\mathrm{NO}_{3}{ }^{-}\right)$assimilation, are removed from solution in $\mathrm{H}_{2} \mathrm{~S}$-bearing waters. These metals, therefore, directly couple ocean redox conditions to $\mathrm{N}$ bioavailability-leading us to question the common assumption that biological $\mathrm{N}_{2}$ fixation precludes $\mathrm{N}$ limitation of the biosphere on geologic time scales.

$\mathrm{Fe}$ is effectively removed from solution in both oxic and sulfidic conditions. In the anoxic Archean oceans, the Fe concentration may have been as high as $50 \mu \mathrm{M}$ (2), as opposed to concentrations more than three orders of magnitude lower in both modern oxygenated seawater (74) and sulfidic deep waters of the chemically stratified Black Sea (75) - the closest modern analog to a sulfidic ocean. Hence, Fe availability surely declined from the Archean to the mid-Proterozoic, whether the deep sea became more oxidized or reduced (76).

Mo forms the highly mobile molybdate anion $\left(\mathrm{MoO}_{4}{ }^{2-}\right)$ under oxidizing conditions. Hence, today Mo is the most abundant transition metal in the oceans, with a concentration of $105 \mathrm{nM}$ and an ocean residence time of $\sim 8 \times$ $10^{5}$ years (77-79). In the presence of $\mathrm{H}_{2} \mathrm{~S}, \mathrm{Mo}$ is readily removed to sediments by reduction to insoluble sulfides or conversion to particle-reactive thiomolybdate $\left(\mathrm{MoS}_{4}{ }^{2-}\right)(80)$. Therefore, in the Black Sea, Mo concentrations fall from $\sim 40 \mathrm{nM}$ in oxygenated surface waters to $\sim 3$ $\mathrm{nM}$ below the chemocline (81). Such removal would have limited the Mo concentration in mid-Proterozoic seawater (82). Sulfidic waters cover only $\sim 0.3 \%$ of the sea floor today, localized in areas of restricted circulation and high productivity, but may account for as much as $\sim 40 \%$ of Mo removal $(77,79)$. We infer that Mo surface concentrations in the late Paleoproterozoic and early Mesoproterozoic oceans were less than $10 \%$ of present levels if sulfidic conditions covered $>10 \%$ of the sea floor (83).

A similar set of arguments can be made for some other bioessential metals that are also less available under sulfidic conditions, such as $\mathrm{Cu}, \mathrm{Zn}$, and $\mathrm{Cd}(84)$. The mid-Proterozoic interval may thus be the only extended period in Earth history during which $\mathrm{Fe}$, $\mathrm{Mo}$, and some other redox-sensitive, bioessential metals were simultaneously scarce in the oceans (Fig. 2) (85).

If so, the consequences for biology would have been profound. The energy-intensive process of $\mathrm{N}_{2}$ fixation, a capability limited to some bacteria and archaea, can be catalyzed by three known nitrogenase metalloenzyme systems. Each requires $\mathrm{Fe}$, in the form of $\mathrm{Fe}-\mathrm{S}$ clusters. The best studied nitrogenase, present in all known diazotrophs, also requires Mo as part of a $\mathrm{Fe}_{7} \mathrm{MoS}_{9}$ cluster (86). In a number of organisms, two "alternative" nitrogenases - genetically distinct but clearly homologous with MoFe-nitrogenase - use $\mathrm{V}$ and $\mathrm{Fe}$, or $\mathrm{Fe}$ alone, but not $\mathrm{Mo}(87,88)$. The mechanism by which these enzyme systems reduce $\mathrm{N}_{2}$ remains elusive (89). The specific activity of MoFe-nitrogenase for $\mathrm{N}_{2}$ reduction appears to be $\sim 1.5$ times that of VFe-nitrogenase at $\sim 30^{\circ} \mathrm{C}(90)$, and it is at least this much more efficient than Fe-nitrogenase (87), which helps to explain the prevalence of MoFe-nitrogenase in the modern environment (91).

Chemostat experiments (92) have shown that nitrogenase expression is regulated by Mo concentration. Alternative nitrogenase expression begins when $\mathrm{Mo}<100 \mathrm{nM}$, and $\mathrm{MoFe}-$ nitrogenase is not expressed when Mo $<25$ $\mathrm{nM}$, about one-fourth the concentration in modern seawater. Hence, it seems likely that the less efficient alternative nitrogenases had prominent roles in global $\mathrm{N}$ cycling until the oceans were thoroughly oxygenated.

Redox-sensitive metals are also important in other parts of the $\mathrm{N}$ cycle. Mo, as part of a molybdopterin cofactor, is found in the nitrate reductase enzymes used for $\mathrm{NO}_{3}{ }^{-}$assimilation by eukaryotes and some prokaryotes, and in the nitrate reductases used by some prokaryotes in $\mathrm{NO}_{3}{ }^{-}$respiration ("denitrification") (93-95). Chemoautotrophs that oxidize ammonia ("nitrification") use the Mo enzyme nitrite oxidoreductase (94) and probably also use $\mathrm{Cu}$ in ammonia monooxygenase (96). $\mathrm{Cu}$ is also used in both nitrite and $\mathrm{N}_{2} \mathrm{O}$ reductases (97). Fe appears to be necessary for all these processes as well as for $\mathrm{NO}$ reduction $(93,96,97)$. 


\section{SCIENCE'S COMPASS}

It follows that the development of sulfidic Proterozoic oceans would have initiated a period of exceptional $\mathrm{N}$ stress for the biosphere. Before this development, in the Fe-rich Archean and Paleoproterozoic oceans, biological $\mathrm{N}_{2}$ fixation dominated by Fe-nitrogenase probably accounted for most of the fixed N supply (98). MoFe-nitrogenase was likely unimportant because, as with S, input of Mo from weathering would have been limited under an atmosphere with only trace $\mathrm{O}_{2}$. Regardless of metal abundances, nitrification and denitrification were
(102). At the same time, rising $\mathrm{PO}_{2}$ likely led to biological nitrification and denitrification becoming important on a global scale. These processes, although hampered by metal scarcity, would have converted $\mathrm{NH}_{4}{ }^{+}$in surface seawater to $\mathrm{NO}_{3}{ }^{-}, \mathrm{NO}_{2}{ }^{-}$, $\mathrm{N}_{2}$, and $\mathrm{N}_{2} \mathrm{O}$. Although $\mathrm{NO}_{3}{ }^{-}$and $\mathrm{NO}_{2}{ }^{-}$are bioavailable forms of fixed $\mathrm{N}$ today, their utility would have been limited in the midProterozoic because of the Mo (and $\mathrm{Fe}$ ) requirement of the various nitrate reductase enzymes. Because $\mathrm{N}_{2}$ and $\mathrm{N}_{2} \mathrm{O}$ are volatile

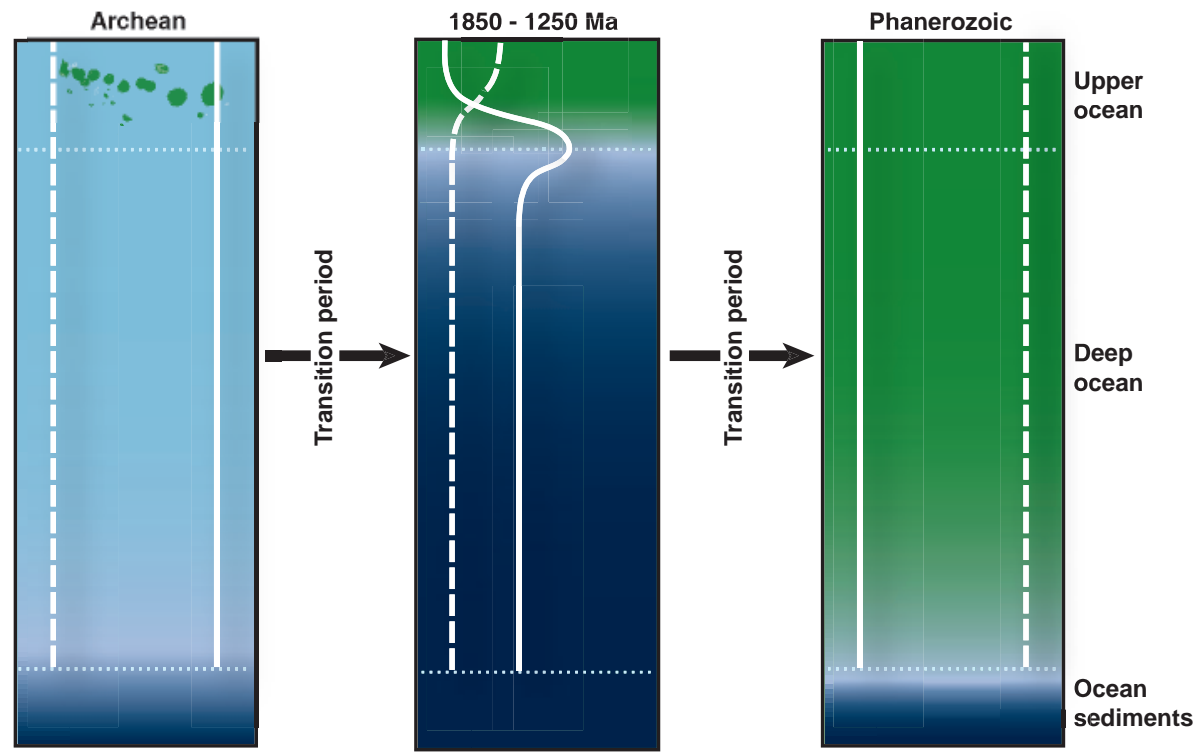

Fig. 2. Schematic depiction of effects of changing ocean redox conditions on the depth distributions of Mo (dashed lines) and Fe (solid lines). Influences of nutrient-type depletion and aeolian inputs on surface seawater concentrations are omitted for simplicity. Color gradations are the same as in Fig. 1. During the Archean, oceans are anoxic but not sulfidic. Significant $\mathrm{O}_{2}$ is only associated with cyanobacterial "blooms." Mo is scarce because it is not readily mobilized from crustal rocks during weathering under low $P_{2}$. Fe is abundant in the absence of $\mathrm{O}_{2}$ and $\mathrm{H}_{2} \mathrm{~S}$. From 1850 to $1250 \mathrm{Ma}$, moderate $\mathrm{PO}_{2}$ oxygenates surface waters but sulfidic deep waters develop. Mo is scarce because of rapid removal in sulfidic waters. Mo is somewhat elevated at the surface because of upper ocean oxygenation and enhanced oxidative weathering. $\mathrm{Fe}$, as in the modern Black Sea, is depleted in sulfidic deep waters, severely depleted in oxic surface waters, and enriched near the redoxcline where both $\mathrm{O}_{2}$ and $\mathrm{H}_{2} \mathrm{~S}$ are scarce. During the Phanerozoic, $\mathrm{O}_{2}$ penetrates to the sediment-water interface. Mo and Fe distributions are similar to today's. See text for details and references.

likely of minor importance before oxygenation of the surface ocean (99). Hence, denitrification as a pathway for loss of fixed $\mathrm{N}$ was minor as long as $\mathrm{PO}_{2}$ remained low. Fixed $\mathrm{N}$ may have been relatively abundant in the form of the ammonium ion $\left(\mathrm{NH}_{4}{ }^{+}\right)$and was probably lost primarily by burial of organic $\mathrm{N}$ in sediments and loss of volatile $\mathrm{NH}_{3}$ to the atmosphere. Phosphate was likely the limiting nutrient (49).

The situation would have changed after $\sim 1800$ Ma. Global rates of $\mathrm{N}_{2}$ fixation presumably decreased because of the decrease in ocean $\mathrm{Fe}$, particularly if-in contrast to modern oceans - the use of the more efficient MoFe-nitrogenase was limited by Mo scarcity $(100,101)$. The antagonistic effect of $\mathrm{O}_{2}$ on nitrogenase activity may also have been important before the development of compensatory strategies shorter than ocean mixing times, which are on the order of 1000 years. In contrast, the residence time of dissolved $\mathrm{P}$ is $>10,000$ years in oxygenated oceans $(51,105,106)$ and perhaps longer in sulfidic oceans. Therefore, the effect of a typical orogenic episode on the availability of bioessential metals, and hence on ocean productivity, would have been local or regional and variable with time, rather than global and persistent (as is the case with $\mathrm{P}$ today). Lower overall productivity in the mid-Proterozoic, inferred from $\delta^{13} \mathrm{C}_{\text {carb }}$, is also consistent with $\mathrm{N}$ stress and with the scarcity of other micronutrients (e.g., $\mathrm{Zn}, \mathrm{Cd})$ (107).

Fe scarcity apparently limits $\mathrm{N}_{2}$ fixation in parts of the modern, oxygenated oceans [e.g., (108-110)], but the global bioavailability of fixed $\mathrm{N}$ is probably less constrained today for three reasons. First, because of the higher specific activity of MoFe-nitrogenase compared to the alternative nitrogenases, and the heavy Fe requirement of all the nitrogenases, the availability of Mo in oxygenated oceans may substantially reduce the impact of Fe limitation on biospheric $\mathrm{N}$ fixation rates. Second, Mo availability facilitates assimilation of $\mathrm{NO}_{3}{ }^{-}$ as an $\mathrm{N}$ source, as well as exploitation of $\mathrm{NO}_{3}{ }^{-}$reduction to drive metabolism in suboxic environments with abundant $\mathrm{NO}_{3}{ }^{-}$. Third, the Phanerozoic development of a vigorous terrestrial $\mathrm{N}$ cycle introduced a new source of fixed N, largely unconstrained by metal availability, to the oceans. Although the $\mathrm{N}$ budget is not tightly quantified, at least as much $\mathrm{N}_{2}$ is fixed each year on land as in the oceans (111). The transfer of even a small fraction of this fixed $\mathrm{N}$ from land to sea may have an important impact on the ocean $\mathrm{N}$ budget.

\section{Implications for Eukaryote Evolution}

Compared with autotrophic bacteria and archaea, photosynthetic eukaryotes are poorly equipped to cope with $\mathrm{N}$-limited oceans in at least three ways. First, and most obviously, eukaryotes lack the capacity for biological $\mathrm{N}_{2}$ fixation and must assimilate fixed $\mathrm{N}$ from their surroundings. Mo and $\mathrm{Cu}$ scarcity in sulfidic oceans would have exacerbated this problem by limiting the ability of eukaryotes to assimilate $\mathrm{NO}_{3}^{-}$and $\mathrm{NO}_{2}^{-}$. Second, red algae and most green algae (the two algal clades with chloroplasts descended directly from cyanobacterial endosymbionts) and all multicellular members of these groups secrete cellulosic cell walls that preclude ingestion of N-bearing organic particles. Third, in living cyanobacteria, $\mathrm{NH}_{4}{ }^{+}$depletion induces formation of a transcriptional regulator, which in turn unleashes a battery of enzymes that efficiently scavenge bioavailable $\mathrm{N}$ from seawater $(112,113)$. Eukaryotes lack this ability. 


\section{SCIENCE'S COMPASS}

Under conditions of nutrient limitation, therefore, eukaryotic algae compete poorly against cyanobacteria (114). Indeed, eukaryotic algae with larger cells (i.e., the seaweeds and net plankton most likely to be recognized as eukaryotic in the fossil record) compete most effectively when $\mathrm{N}$ availability exceeds their immediate metabolic needs, allowing them to store fixed $\mathrm{N}$ in intracellular vacuoles; $\mathrm{NH}_{4}^{+}$is not easily stored. Thus, in modern oceans the growth of larger algae is facilitated by high $\mathrm{NO}_{3}{ }^{-}$levels $(115,116)$. As a consequence of these limitations, midProterozoic eukaryotic algae would likely have fared best in coastal and estuarine habitats where proximity to riverine metal sources minimized the effects of metal limitation, and where upwelling of $\mathrm{NH}_{4}{ }^{+}$-bearing deep waters could have provided an adequate source of bioavailable N.

Greatly enhanced weathering associated with the extensive Grenville orogeny at $\sim 1250$ Ma may have increased the supply of metals to the oceans. Enhanced burial of organic C initiated at this time may also have led to a modest rise in $\mathrm{PO}_{2}$ (45). Together, these effects could have eased $\mathrm{N}$ limitation, facilitating limited eukaryotic diversification as the Neoproterozoic Era began (Fig. 1D). The contemporaneous termination of $\delta^{13} \mathrm{C}$ stasis (45), suggestive of an intensification of the link between primary production and tectonics, is consistent with this scenario. However, only with the later Neoproterozoic appearance of more fully oxic oceans would the increased availability of $\mathrm{Mo}$ and $\mathrm{Cu}$ have facilitated the biological assimilation of $\mathrm{NO}_{3}{ }^{-}$and $\mathrm{NO}_{2}{ }^{-}$. Such assimilation would have greatly expanded the pool of bioavailable N, returned the oceans to a phosphate-limited regime, and enabled algae to diversify throughout the marine realm.

The known fossil record of eukaryotic algae is subject to preservational biases but is consistent with this scenario $(62,67-71,117$ 119 ). Latest Proterozoic animal diversification, itself likely influenced by renewed oxygenation, would further have facilitated algal diversification via ecological interactions $(59,69)$.

\section{Conclusions and Future Directions}

Earth's "middle age" is emerging as neither a direct extension of its youth nor a simple prelude to its current state. At present we know just enough about this period to develop intriguing hypotheses connecting life and environments. The hypothesis presented here, consistent with available data, provides a compelling explanation for observed patterns of early eukaryote evolution. However, in view of the limitations of available data, it should be regarded primarily as a new lens through which to focus research.

In the geosciences, this hypothesis should help to motivate further investigations into Pro- terozoic environments and biology. Specifically, further work is needed to substantiate the inferences drawn from $\delta^{34} \mathrm{~S}$, to better constrain the timing and mechanism(s) of redox transitions, to determine the effects of these transitions on ocean biogeochemistry, and to tease more paleobiological information from the geologic record. New approaches may be helpful, including study of redox-sensitive metal abundances in sediments $(31,120), \delta^{34} \mathrm{~S}$ of carbonate-associated sulfate $(36,121)$, mass-independent $\mathrm{S}$ isotope effects (7), and mass-dependent fractionation of Mo isotopes (122). Development of a reliable proxy for marine $\mathrm{N}$ isotopes would help to shed light on perturbations of the $\mathrm{N}$ cycle. Molecular biosignatures can provide an improved perspective on the relative abundances of prokaryotes and eukaryotes in Proterozoic oceans. Progress will come most rapidly if these and other techniques are applied by multidisciplinary teams working in an integrated manner on stratigraphic sequences of paleoenvironmental importance.

The hypothesis articulated here also suggests that bioinorganic chemistry, broadly defined, can provide unique insights into the coevolution of life and environment $(72,73)$. Integrated study of genetic diversity, (metallo)enzyme gene expression, and elemental bioavailability in natural systems may be useful in unraveling life's history on Earth (and evaluating the prospects for life elsewhere). This should be fertile ground for research as the nascent subdisciplines of geobiology and astrobiology unfold.

\section{References and Notes}

1. P. Cloud, Am. J. Sci. 272, 537 (1972)

2. H. D. Holland, Econ. Geol. 68, 1169 (1973)

3. Geochemical evidence of a hydrothermal source for Fe in BIFs is presented in $(123,124)$.

4. H. D. Holland, N. J. Beukes, Am. J. Sci. 290A, 1 (1990).

5. J. A. Karhu, H. D. Holland, Geology 24, 867 (1996) 6. B. Rasmussen, R. Buick, Geology 27, 115 (1999)

7. J. Farquhar, H. M. Bao, M. Thiemens, Science 289, 756 (2000).

8. D. E. Canfield, Nature 396, 450 (1998).

9. The Archean, Proterozoic, and Phanerozoic Eons span the intervals 3800 to $2500 \mathrm{Ma}, 2500$ to 543 $\mathrm{Ma}$, and 543 to $0 \mathrm{Ma}$, respectively. The Paleoproterozoic, Mesoproterozoic, and Neoproterozoic Eras span the intervals 2500 to $1600 \mathrm{Ma}, 1600$ to 1000 $\mathrm{Ma}$, and 1000 to $543 \mathrm{Ma}$, respectively. Here, "midProterozoic" refers to the interval 1800 to $1250 \mathrm{Ma}$.

10. A. H. Knoll, J. M. Hayes, A. J. Kaufman, K. Swett, I. B. Lambert, Nature 321, 832 (1986).

11. D. J. DesMarais, H. Strauss, R. E. Summons, J. M. Hayes, Nature 359, 605 (1992).

12. D. E. Canfield, A. Teske, Nature 382, 127 (1996).

13. A. J. Kaufman, A. H. Knoll, G. M. Narbonne, Proc. Natl. Acad. Sci. U.S.A. 94, 6600 (1997).

14. B. Runnegar, Alcheringa 6, 223 (1982).

15. A. H. Knoll, in Origin and Early Evolution of the Metazoa, J. H. Lipps, P. W. Signor, Eds. (Plenum, New York, 1992), pp. 53-84.

16. Anoxic conditions amenable to BSR occurred at least locally and sporadically since the Archean, as they do today in the waters of restricted ocean basins and in marine sediments.

17. For a review of relevant $S$ isotope systematics, see (125).

18. Mass-dependent $S$ isotope fractionation is com- monly expressed as $\delta^{34} \mathrm{~S}=\%$ o deviation in ${ }^{34} \mathrm{~S} /{ }^{32} \mathrm{~S}$ from the Canyon Diablo Troilite (CDT) standard $=$ $\left[\left({ }^{34} \mathrm{~S} /{ }^{32} \mathrm{~S}\right)_{\text {sample }} /\left({ }^{34} \mathrm{~S} /{ }^{32} \mathrm{~S}\right)_{\mathrm{CDT}}-1\right] \times 1000$.

19. D. E. Canfield, B. Thamdrup, Science 266, 1973 (1994).

20. K. S. Habicht, D. E. Canfield, Geology 29, 555 (2001).

21. $\delta^{34} \mathrm{~S}$ depletion of $\mathrm{H}_{2} \mathrm{~S}$ relative to $\mathrm{SO}_{4}{ }^{2-}$ in Black Sea waters is $>45 \%$ o [(19) and references therein], hence ${ }^{34} \mathrm{~S}$ depletion by $\mathrm{S}^{0}$ disproportionation does not require a completely oxic water column. However, in redox-stratified oceans with low- $\mathrm{H}_{2} \mathrm{~S}$ surface waters, anoxygenic photosynthesis, which produces little $S$ isotope fractionation while converting $\mathrm{H}_{2} \mathrm{~S}$ to $\mathrm{SO}_{4}{ }^{2-}$, may dominate $\mathrm{S}$ cycling in the photic zone. Therefore, $S$ isotope fractionation of $>45 \%$ 。 suggests $\mathrm{O}_{2}$ penetration at least below the photic zone [see (12) and references therein]

22. Precambrian $\mathrm{S}$ isotope data and interpretations are reviewed by Canfield and colleagues in (8) and (125); see also $(126,127)$.

23. Y. A. Shen, R. Buick, D. E. Canfield, Nature 410, 77 (2001).

24. A different interpretation is given in $(128,129)$. But see also a rebuttal in (130).

25. The extent of $\mathrm{S}$ isotope fractionation by biochemical effects may be restricted by reservoir effects, whereby preferential loss of ${ }^{32} \mathrm{~S}$ from the $\mathrm{SO}_{4}{ }^{2-}$ reservoir progressively enriches the reservoir in ${ }^{44} \mathrm{~S}$. $\mathrm{H}_{2} \mathrm{~S}$ subsequently produced is enriched in ${ }^{34} \mathrm{~S}$ compared to the maximum depletion possible when $\mathrm{SO}_{4}{ }^{2-}$ is abundant.

26. D. E. Canfield, T. W. Lyons, R. Raiswell, Am. J. Sci. 296, 818 (1996).

27. T. W. Lyons, Geochim. Cosmochim. Acta 61, 3367 (1997).

28. R. Raiswell, R. Newton, P. B. Wignall, J. Sed. Res. 71, 286 (2001).

29. P. B. Wignall, R. Newton, Sediment. Geol. 144, 335 (2001).

30. Y. Shen, D. E. Canfield, A. H. Knoll, Am. J. Sci., 302 81 (2002).

31. T. W. Lyons, J. P. Werne, D. J. Hollander, R. W. Murray, Chem. Geol., in press.

32. J. J. Luepke, T. W. Lyons, Precambrian Res. 111, 79 (2001).

33. T. W. Lyons, J. J. Luepke, M. E. Schreiber, G. A. Zieg, Geochim. Cosmochim. Acta 64, 427 (2000).

34. L. C. Kah, T. W. Lyons, J. T. Chesley, Precambrian Res. 111, 203 (2001).

35. G. E. Claypool, W. T. Holser, I. R. Kaplan, H. Sakai, I. Zak, Chem. Geol. 28, 199 (1980).

36. M. T. Hurtgen, M. A. Arthur, N. S. Suits, A. J. Kaufman, Earth Planet. Sci. Lett., in press.

37. Mass-dependent $C$ isotope fractionation is commonly expressed as $\delta^{13} \mathrm{C}=\%$ o deviation in ${ }^{13} \mathrm{C} /{ }^{12} \mathrm{C}$ from the Pee Dee Belemnite (PDB) standard = $\left[\left({ }^{13} \mathrm{C} /{ }^{12} \mathrm{C}\right)_{\text {sample }} /\left({ }^{13} \mathrm{C} /{ }^{12} \mathrm{C}\right)_{\mathrm{PDB}}-1\right] \times 1000$.

38. J. M. Hayes, H. Strauss, A. J. Kaufman, Chem. Geol. 161, 103 (1999).

39. R. M. Ganels, F. T. MacKenzie, Evolution of Sedimentary Rocks (Norton, New York, 1971), pp. 119-131.

40. A. J. Kaufman, A. H. Knoll, Precambrian Res. 73, 27 (1995).

41. J. L. Kirschvink et al., Proc. Natl. Acad. Sci. U.S.A. 97, 1400 (2000)

42. A. Bekker et al., Am. J. Sci. 301, 261 (2001).

43. R. Buick, D. J. DesMarais, A. H. Knoll, Chem. Geol. 123, 153 (1995).

44. M. D. Brasier, J. F. Lindsay, Geology 26, 555 (1998).

45. L. C. Kah, A. G. Sherman, G. M. Narbonne, A. H. Knoll, A. J. Kaufman, Can. J. Earth Sci. 36, 313 (1999).

46. A. H. Knoll, A. J. Kaufman, M. A. Semikhatov, Am. J. Sci. 295, 823 (1995).

47. J. K. Bartley et al., Precambrian Res. 111, 165 (2001). 48. E. M. Moores, Geol. Soc. Am. Bull. 114, 80 (2002). 49. C. J. Bjerrum, D. E. Canfield, Nature 417, 159 (2002).

50. P. Van Cappellen, E. D. Ingall, Paleoceanography $\mathbf{9}$, 677 (1994).

51. A. S. Colman, H. D. Holland, SEPM Spec. Pub. 66 (2000), p. 53.

52. J. Veizer, R. N. Clayton, R. W. Hinton, Geochim Cosmochim. Acta 56, 875 (1992).

53. J. Veizer, K. A. Plumb, R. N. Clayton, R. W. Hinton, 


\section{SCIENCE'S COMPASS}

J. P. Grotzinger, Geochim. Cosmochim. Acta 56, 2487 (1992).

54. P. Kroopnick, Deep-Sea Res. 32, 57 (1985)

55. N. J. Beukes, C. Klein, A. J. Kaufman, J. M. Hayes, Econ. Geol. 85, 663 (1990).

56. C. R. Calver, Precambrian Res. 100, 121 (2000).

57. P. F. Hoffman, A. J. Kaufman, G. P. Halverson, D. P. Schrag, Science 281, 1342 (1998)

58. T. M. Han, B. Runnegar, Science 257, 232 (1992).

59. A. H. Knoll, Proc. Natl. Acad. Sci. U.S.A. 91, 6743 (1994).

60. J. J. Brocks, G. A. Logan, R. Buick, R. E. Summons, Science 285, 1033 (1999)

61. R. E. Summons, M. R. Walter, Am. J. Sci. 290A, 212 (1990)

62. E. J. Javaux, A. H. Knoll, M. R. Walter, Nature 412, 66 (2001)

63. N. J. Butterfield, Precambrian Res. 111, 235 (2001)

64. Acritarchs are closed, organic-walled microfossils of uncertain systematic relationships; most are thought to be the vegetative or reproductive walls of eukaryotic algae.

65. P. Y. Petrov, A. F. Veis, Stratigr. Geol. Correl. 3, 435 (1995)

66. S. H. Xiao, A. H. Knoll, Y. Zhang, L. Yin, Precambrian Res. 84, 197 (1997).

67. G. Vidal, J. P. Nystuen, Am. J. Sci. 290A, 170 (1990)

68. M. Steiner, Berliner Geowiss. Abh. E 15, 1 (1994).

69. N. J. Butterfield, Paleobiology 23, 247 (1997).

70. X. L. Yuan, R. J. Cao, Lethaia 32, 143 (1999).

71. S. H. Xiao, X. L. Yuan, M. Steiner, A. H. Knoll, J. Paleontol. 76, 345 (2001).

72. J. J. R. Frausto da Silva, R. J. P. Williams, The Biological Chemistry of the Elements: The Inorganic Chem istry of Life (Clarendon, Oxford, UK, 1991).

73. R. J. P. Williams, J. J. R. Frausto da Silva, Biochem Biophys. Res. Commun. 292, 293 (2002)

74. J. F. Wu, E. Boyle, W. Sunda, L.-S. Wen, Science 293 , 847 (2001).

75. B. L. Lewis, W. M. Landing, Deep-Sea Res. 38, S773 (1991).

76. Fe abundance in oxygenated mid-Proterozoic surface waters was likely lower than in sulfidic deep waters, as implied by the relative solubilities of $\mathrm{Fe}$ oxyhydroxides and sulfides and the Black Sea analog. Reduced mobility of Fe during weathering after the rise of $\mathrm{O}_{2}$ would also have contributed to low surface water Fe concentrations. However, Fe availability may have been higher than in modern, oxygenated oceans because Fe concentrations are elevated in the anoxic but nonsulfidic waters that would have characterized the redoxcline in such chemically stratified oceans.

77. K. K. Bertine, K. K. Turekian, Geochim. Cosmochim Acta 37, 1415 (1973).

78. R. W. Collier, Limnol. Oceanogr. 30, 1351 (1985)

79. J. L. Morford, S. Emerson, Geochim. Cosmochim. Acta 63, 1735 (1999).

80. G. R. Helz et al., Geochim. Cosmochim. Acta 60 , 3631 (1996)

81. S. R. Emerson, S. S. Huested, Mar. Chem. 34, 177 (1991)

82. Mo is supplied to the upper part of the Black Sea primarily by regional rivers with Mo concentrations four times that of global-average river water (131). Therefore, Mo concentrations in the Black Sea generally, and especially near the surface, are higher than would be expected in analogous portions of the hypothesized sulfidic mid-Proterozoic oceans far from riverine sources. Fe concentrations in the Black Sea- $\sim 20 \mathrm{nM}$ at depth (75) —are also likely elevated by proximity to riverine and aeolian sources.

83. Mo depletion can be illustrated by a simple two-box steady-state model of the oceans in which riverine input is balanced by removal to sediments. Removal is assumed to be roughly proportional to the concentration of Mo in deep waters and to the area of sulfidic sea floor, and removal constants are calibrated against the modern Mo budget. Such a model captures the first-order features of the Mo budget because sulfidic sediments are the most efficient sink for Mo from the oceans (although it should be noted that the importance of Mo removal in sulfidic sediments that form beneath the sediment-wate interface is unclear). We assume modern rates of mixing between the deep sea and a surface layer $\sim 100 \mathrm{~m}$ deep, and a riverine Mo flux comparable to the modern. There is no evidence of substantially reduced ocean circulation during this time. Although physical stratification and large fluxes of organic $C$ are prerequisites to generating anoxic waters today, this would not have been the case under an atmosphere containing only a fraction of present-day $\mathrm{PO}_{2}$. Even lower Mo concentration is expected if, as seems likely, the riverine Mo flux was lower under an atmosphere with lower $\mathrm{PO}_{2}$

84. B. L. Lewis, W. M. Landing, Mar. Chem. 40, 105 (1992).

85. Compared to today, an elevated dust budget was possible in a Precambrian world without rooted terrestrial vegetation. As it is today, dust could have been an important source of Fe to the mid-Proterozoic oceans because of the high concentration of Fe in the crust. By comparison, aeolian delivery of Mo and most other transition metals was likely unimportant because their crustal concentrations are many orders of magnitude lower.

86. J. B. Howard, D. C. Rees, Chem. Rev. 96, 2965 (1996).

87. R. R. Eady, Chem. Rev. 96, 3013 (1996)

88. A fourth nitrogenase, structurally distinct from the other three, has recently been identified in the chemoautotroph Streptomyces thermoautotrophicus (132). It also appears to require Mo and $\mathrm{Fe}$, and its importance in nature is unknown.

89. E. I. Stiefel, Pure Appl. Chem. 70, 889 (1998).

90. R. W. Miller, R. R. Eady, Biochem. J. 256, 429 (1988).

91. Because the specific activity of MoFe-nitrogenase is lower than that of VFe-nitrogenase at temperatures $<10^{\circ} \mathrm{C}(90)$, VFe-nitrogenase may be more important in nature than is generally appreciated.

92. R. D. Joerger, P. E. Bishop, Crit. Rev. Microbiol. 16, (1988).

93. R. Hille, Chem. Rev. 96, 2757 (1996)

94. P. M. H. Kroneck, D. J. Abt, in Molybdenum and Tungsten-Their Roles in Biological Processes, A. Sigel, H. Sigel, Eds., vol. 39 of Metal lons in Biological Systems (Dekker, New York, 2002), pp. 369-403.

95. Mo-free dissimilatory nitrate reductase has been reported (133), and W can replace Mo in some bacterial and archaeal molybdopterin-based enzymes (134).

96. J. A. Zahn, D. M. Arciero, A. B. Hooper, A. A. DiSpirito, FEBS Lett. 397, 35 (1996)

97. W. G. Zumft, Microbiol. Mol. Biol. Rev. 61, 533 (1997).

98. Although $\mathrm{N}_{2}$ can be converted to bioavailable $\mathrm{N}$ by abiotic processes $(135,136)$, the conservation of nitrogenase enzymes across archaeal and bacterial lines (137) is consistent with an ancient origin for this biochemistry, suggesting that the supply of abiogenic fixed $\mathrm{N}$ to the Archean biosphere was inadequate to support early ecosystems.

99. P. G. Falkowski, Nature 387, 272 (1997).

100. Fe availability in surface waters may have decreased earlier, after the development of oxygenic photosynthesis in the Archean, but resupply by upwelling of anoxic, Fe-rich deep waters, evidenced by BIF deposition, presumably prevented biospheric crisis.

101. VFe-nitrogenase may have been particularly important at this time because $V$ sulfides are more soluble than Mo sulfides (73).

102. Strategies used by the marine cyanobacterium Trichodesmium are summarized in (138)

103. V. Beaumont, F. Robert, J. Precambrian Res. 96, 63 (1999).

104. $\delta^{15} \mathrm{~N}$ in kerogen shifts from values as light as $-6 \%$ in the Archean to a Phanerozoic-type range of 0 to $10 \%$ by 2000 to $1600 \mathrm{Ma}$. In the modern oceans, $\mathrm{NO}_{3}{ }^{-}$near the surface is enriched in ${ }^{15} \mathrm{~N}$ because of a kinetic isotope effect during denitrification. Hence, the $\delta^{15} \mathrm{~N}$ shift from the Archean to the Proterozoic has been interpreted as reflecting the initiation of widespread nitrification and denitrification due to increased $\mathrm{PO}_{2}$, with subsequent assimilation of ${ }^{15} \mathrm{~N}$-enriched $\mathrm{NO}_{3}{ }^{-}$. This interpretation may overstate the importance of denitrification and $\mathrm{NO}_{3}{ }^{-}$assimilation in the metal-starved Paleoproterozoic and Mesoproterozoic oceans. $\mathrm{N}$ isotopes are also strongly fractionated during biosynthetic uptake of $\mathrm{NH}_{4}^{+}$such that biological $\mathrm{N}$ is depleted in
${ }^{15} \mathrm{~N}$ when $\mathrm{NH}_{4}{ }^{+}$is in excess $(139,140)$. Therefore, a transition from $\mathrm{NH}_{4}{ }^{+}$-rich surface waters in the Archean to $\mathrm{NH}_{4}{ }^{+}$-poor conditions in the Proterozoic could contribute to a shift to heavier $\delta^{15} \mathrm{~N}$ values in kerogens.

105. K. C. Ruttenberg, Chem. Geol. 107, 405 (1993).

106. G. M. Filippelli, M. L. Delaney, Geochim. Cosmochim. Acta 60, 1479 (1996).

107. Carbonic anhydrase, important for uptake of inorganic carbon, is a $\mathrm{Zn}$ enzyme in eukaryotes and prokaryotes and a Cd enzyme in some marine diatoms (141-143)

108. J. H. Martin, S. E. Fitzwater, Nature 331, 341 (1988).

109. P. G. Falkowski, R. T. Barber, V. Smetacek, Science 281, 200 (1998).

110. J. F. Wu et al., Science 289, 759 (2000)

111. For recent perspectives on the $\mathrm{N}$ cycle, see (144146).

112. D. Lindell et al., J. Bacteriol. 180, 1878 (1998)

113. A. Herrero et al., J. Bacteriol. 183, 411 (2001).

114. D. Lindell et al., Limnol. Oceanogr. 40, 1130 (1995)

115. T. C. Malone, in Primary Productivity in the Sea, P. C. Falkowski, Ed. (Plenum, New York, 1980), pp. 301-319.

116. D. Gilbert et al., Hydrobiologia 374, 111 (1998).

117. W. L. Zang et al., Precambrian Res. 57, 243 (1992).

118. Y. Zhang et al., Paleontol. Soc. Mem. 50, 1 (1998).

119. Brasier and Lindsay (44) alternatively proposed that the mid-Proterozoic oceans were $\mathrm{P}$ limited. However, there is no compelling connection between $\mathrm{P}$ limitation and delayed eukaryotic diversification.

120. A. Bekker et al., paper presented at the 12 th annual V. M. Goldschmidt Conference, Zürich, 18 to 23 August 2002.

121. H. Strauss, Chem. Geol. 161, 89 (1999).

122. J. Barling et al., Earth Planet. Sci. Lett. 193, 447 (2001).

123. S. B. Jacobsen, M. R. Pimentel-Klose, Geophys. Res. Lett. 15, 393 (1988)

124. L. A. Derry, S. B. Jacobsen, Geochim. Cosmochim. Acta 54, 2965 (1990).

125. D. E. Canfield, R. Raiswell, Am. J. Sci. 299, 697 (1999), and references therein.

126. E. M. Cameron, Nature 296, 145 (1982)

127. H. Strauss, Precambrian Res. 63, 225 (1993).

128. H. Ohmoto, R. P. Felder, Nature 328, 244 (1987).

129. H. Ohmoto et al., Science 262, 555 (1993).

130. D. E. Canfield et al., Science 288, 658 (2000).

131. D. Colodner, J. Edmond, E. Boyle, Earth Planet. Sci. Lett. 131, 1 (1995)

132. M. Ribbe, D. Gadkari, O. Meyer, J. Biol. Chem. 272 26627 (1997).

133. A. N. Antipov, N. N. Lyalikova, T. V. Khijniak, N. P. L'vov, FEBS Lett. 441, 257 (1998)

134. M. K. Johnson, D. C. Rees, M. W. W. Adams, Chem Rev. 96, 2817 (1996).

135. Y. L. Yung, M. B. McElroy, Science 203, 1002 (1979)

136. J. A. Brandes et al., Nature 395, 365 (1998).

137. J. P. Zehr, E. J. Carpenter, T. A. Villareal, Trends Microbiol. 8, 68 (2000)

138. D. G. Capone, J. P. Zehr, H. W. Paerl, B. Bergman, E. J. Carpenter, Science 276, 1221 (1997).

139. D. J. Velinsky, M. L. Fogel, J. F. Todd, B. M. Tebo, Geophys. Res. Lett. 18, 649 (1991).

140. M. P. Hoch, M. L. Fogel, D. L. Kirchman, Geomicrobiol. J. 12, 113 (1994)

141. F. M. M. Morel et al., Nature 369, 740 (1994).

142. T. W. Lane, F. M. M. Morel, Proc. Natl. Acad. Sci. U.S.A. 94, 4627 (2000)

143. K. S. Smith, J. G. Ferry, FEMS Microbiol. Rev. 24, 335 (2000).

144. P. M. Vitousek et al., Ecol. Appl. 7, 737 (1997)

145. D. G. Capone, Curr. Opin. Microbiol. 4, 341 (2001), and references therein.

146. J. P. Zehr, B. B. Ward, Appl. Environ. Microbiol. 68 1015 (2002).

147. S. M. Porter, A. H. Knoll, Paleobiology 26, 360 (2000).

148. We thank M. Anbar, R. Buick, D. E. Canfield, A. S Colman, R. R. Eady, P. G. Falkowski, A. J. Kaufman, J. McCarthy, K. H. Nealson, A. Post, Y. Shen, and E. I. Stiefel for helpful discussions. N. Butterfield and T. W. Lyons provided insightful reviews. Supported by NSF grants CHE 9714282 and EAR 0106712 (A.D.A.) and by the NASA Astrobiology Institute. 